\title{
Isolation and Identification of Respiratory Nitrate Reductase-Producing Bacteria from Soil and Production of the Enzyme
}

\author{
Kenji Aoki, Riu SHINke and Hiroshi NishirA \\ Department of Agricultural Chemistry, Faculty of Agriculture, \\ Kobe University, Rokko, Kobe 657, Japan \\ Received June 19, 1980
}

\begin{abstract}
A bacterial strain MY-12, isolated from rice field soil, and identified as Enterobacter cloacae, produced much nitrate reductase in cells in anaerobic culture. Tests were conducted on the growth conditions for anaerobic production of the enzyme. Nitrate was essential for enzyme formation, and iron ions promoted enzyme production. The addition of peptone ( $2 \mathrm{~g} / \mathrm{liter})$ to the synthetic medium increased enzyme production with an increase in growth. The specific activity of the enzyme of this strain, cultured under optimal growth conditions, was higher than that of enzyme of Escherichia coli, Klebsiella aerogenes, Bacillus licheniformis or Micrococcus denitrificans. Nitrate reductase of $E$. cloacae MY-12 produced in anaerobic culture was membrane-bound. Some properties of the solubilized enzyme are described.
\end{abstract}

Respiratory nitrate reductase $(\mathrm{EC}, 1.9 .6 .1)$ is distributed in various species of bacteria. ${ }^{1)}$ The enzyme is formed in cells when they are cultured anaerobically in the presence of nitrate. This is membrane-associated enzyme and it mediates the transfer of electrons from cytochromes to nitrate which acts as a terminal electron acceptor. ${ }^{2)}$ In some bacteria, the enzyme was solubilized from particulate fraction by heat treatment or the use of detergents and purified to homogeneity. ${ }^{2 \sim 6)}$ The molecular, ${ }^{7)}$ chemical $^{6 /}$ and catalytic ${ }^{8)}$ properties of the enzyme have been investigated.

In order to characterize respiratory nitrate reductase in other species of facultative bacteria in rice fields, farms, forests and river beds, we attempted to isolate strains with high enzyme yield. Three strains with high yield were isolated from 120 sources. Strain MY-12 produced the most enzyme of three in anaerobic culture and was used for the present study.

The report describes the isolation of the bacteria producing respiratory nitrate reductase, the identification of the strain, growth conditions for enzyme production and proper- ties of the enzyme.

\section{MATERIALS AND METHODS}

Materials. Lysozyme, RNase and DNase were purchased from Seikagaku Kogyo Co., Tokyo.

Strains. E. cloacae IFO 12935 was obtained from the Institute for Fermentation, Osaka

Soil samples. Soils of rice fields, farms, forests and river beds in Hyogo Prefecture were used for the screening tests.

Isolation of microorganisms. The basal medium for screening consisted of the following per liter: $\mathrm{Na}_{2} \mathrm{HPO}_{4} \cdot 12 \mathrm{H}_{2} \mathrm{O}, 15 \mathrm{~g} ; \quad \mathrm{KH}_{2} \mathrm{PO}_{4}, 3 \mathrm{~g} ;$ glucose, $4 \mathrm{~g}$; $\mathrm{NaNO}_{3}, 1 \mathrm{~g} ; \mathrm{NH}_{4} \mathrm{Cl}, 0.1 \mathrm{~g} ; \mathrm{NaCl}, 0.5 \mathrm{~g} ; \mathrm{MgSO}_{4} \cdot 7 \mathrm{H}_{2} \mathrm{O}$, $0.2 \mathrm{~g}$; and $\mathrm{Na}_{2} \mathrm{MoO}_{4} \cdot 2 \mathrm{H}_{2} \mathrm{O}, 2 \mathrm{mg} ; \mathrm{pH}$ 7.1. A small amount of $\mathrm{NH}_{4} \mathrm{Cl}$ (one-tenth of $\mathrm{NaNO}_{3}$ ) was added to the medium for increasing the growth of microorganisms. About $1 \mathrm{~g}$ of soil was suspended in $10 \mathrm{ml}$ of $0.8 \%$ sterile saline solution. After shaking vigorously for $1 \mathrm{~min}, 1 \mathrm{drop}$ of the supernatant was applied to a plate on which basal medium containing $15 \mathrm{~g} /$ liter of agar was layered, and the plate was placed at $30^{\circ} \mathrm{C}$ for 3 to 7 days. Grown organisms were transferred to a tube containing basal medium and cultured statically at $30^{\circ} \mathrm{C}$ for $24 \mathrm{hr}$. Well-grown organisms were selected and cultured anaerobically in a rubber-stoppered shaking flask filled with $600 \mathrm{ml}$ of medium for $24 \mathrm{hr}$. Cells were collected by centrifugation at 
$9000 \times g$ for $20 \mathrm{~min}$ and disrupted with a Kubota $200 \mathrm{M}$ ultrasonic oscillator at $160 \mathrm{~W}$ for $5 \mathrm{~min}$. Nitrate reductase activity was then assayed. Organisms with high enzyme productivity were selected.

Enzyme assay. Nitrate reductase was assayed by measuring the nitrite liberated by reduction of nitrate with methyl viologen as an electron donor. ${ }^{9}$ The enzyme reaction mixture consisting of $0.5 \mathrm{ml}$ of $0.1 \mathrm{M} \mathrm{K}-\mathrm{Na}$ phosphate buffer, pH 7.1,0.2 $\mathrm{ml}$ of $0.2 \mathrm{M} \mathrm{NaNO}_{3}$ and $0.025 \%$ methyl viologen, and $0.3 \mathrm{ml}$ of enzyme solution was put into a small test tube $(9 \times 120 \mathrm{~mm})$ with a rubber stopper and preincubated at $30^{\circ} \mathrm{C}$ for $3 \mathrm{~min}$. The tube was flushed with $\mathrm{N}_{2}$ to remove the $\mathrm{O}_{2}$. To start the reaction, $0.1 \mathrm{ml}$ of $0.4 \%$ $\mathrm{Na}_{2} \mathrm{~S}_{2} \mathrm{O}_{4}$ prepared freshly in $0.4 \% \mathrm{NaHCO}_{3}$ was added to the mixture. The tube was shaken gently till the mixture turned blue. After incubation for $5 \mathrm{~min}$ at $30^{\circ} \mathrm{C}$, the stopper was removed and the mixture was stirred vigorously with a tube mixer to oxidize the reduced methyl viologen and remaining $\mathrm{Na}_{2} \mathrm{~S}_{2} \mathrm{O}_{4}$. For determination of nitrite, ${ }^{109} 0.5 \mathrm{ml}$ of $1 \%$ sulfanilamide in $9 \% \mathrm{HCl}$ and $0.5 \mathrm{ml}$ of $0.02 \% \mathrm{~N}$-1-naphthylethylenediamine dihydrochloride were added to the mixture. After incubation for $10 \mathrm{~min}$ at room temperature, $1 \mathrm{ml}$ of deionized water was added, and the absorbance at $540 \mathrm{~nm}$ was read. One unit of enzyme activity was defined as the production of $1 \mu \mathrm{mol}$ of nitrite per hr at $30^{\circ} \mathrm{C}$. Specific activity was expressed in units per $\mathrm{mg}$ of protein. Nitrite reductase was assayed by the same method as described above in the reaction mixture containing $\mathrm{NaNO}_{2}$ as an electron acceptor instead of $\mathrm{NaNO}_{3} \cdot{ }^{11}$

Protein assay. Protein was determined by the method of Lowry et al. ${ }^{12}$

Identification of isolated strain. The isolated bacterium was identified according to "Bergey's Manual of Determinative Bacteriology," 8 th ed. ${ }^{13)}$ and the method reported by Sakazaki. ${ }^{14)}$

Growth conditions for enzyme production. For nitrate reductase production, two different anaerobic cultures were carried out. First, a rubber-stoppered shaking flask was filled with $600 \mathrm{ml}$ of medium and flushed with $\mathrm{N}_{2}$. Before inoculation, $20 \mathrm{mg}$ of $\mathrm{Na}_{2} \mathrm{~S}_{2} \mathrm{O}_{4}$ was added to the medium to completely exclude $\mathrm{O}_{2}{ }^{15)}$ Second, the rubberstoppered shaking flask was filled with $600 \mathrm{ml}$ of medium which was rapidly cooled after sterilization, and the strain was inoculated without flushing with $\mathrm{N}_{2}$ or $\mathrm{Na}_{2} \mathrm{~S}_{2} \mathrm{O}_{4}$. No differences in cell growth and enzyme production were observed between the two anaerobic cultures. The second method was employed in the following experiments. After the bacterium was precultured statically in $10 \mathrm{ml}$ of medium at $30^{\circ} \mathrm{C}$ for $8 \mathrm{hr}$, it was transferred to a flask and incubated at $30^{\circ} \mathrm{C}$ for $13 \mathrm{hr}$. Cells were collected by centrifugation at $9000 \times g$ for $20 \mathrm{~min}$, washed with $0.1 \mathrm{M}$ $\mathrm{K}-\mathrm{Na}$ phosphate buffer, $\mathrm{pH} 7.1$, and centrifuged again at
$17,000 \times g$ for $20 \mathrm{~min}$. Wet cells were suspended in $0.1 \mathrm{M} \mathrm{K}$ $\mathrm{Na}$ phosphate buffer, $\mathrm{pH} 7.1(1 \mathrm{~g} \cdot$ wet cell $/ 10 \mathrm{ml})$, and disrupted with the ultrasonic oscillator at $160 \mathrm{~W}$ for $5 \mathrm{~min}$. The cell-free extract was assayed for nitrate and nitrite reductases. The nitrate reductase activity in the cell-free extract was modified by adding the amount of nitrite which was decreased by nitrite reductase in the extract.

Fractionation of cell-free extract. The bacterium cultured anaerobically was incubated with a lysozyme solution containing $100 \mathrm{mg}$ of lysozyme, $1.5 \mathrm{mg}$ of DNase and RNase and $5 \mathrm{~mm}$ EDTA in $100 \mathrm{ml}$ of $0.1 \mathrm{M} \mathrm{Tris}-\mathrm{HCl}$ buffer, $\mathrm{pH} 8.0$, at $30^{\circ} \mathrm{C}$ for $30 \mathrm{~min}$ and sonicated at $60 \mathrm{~W}$ for $1 \mathrm{~min}$. The whole cells were removed by centrifugation at $3000 \times g$ for $10 \mathrm{~min}$. The supernatant was centrifuged at $40,000 \times g$ for $2 \mathrm{hr}$. Nitrate reductase activity was determined in the supernatant and precipitated fractions.

Solubilization of enzyme. The cell-free extract of the bacterium was prepared as described above. After the whole cells were removed by centrifugation at $3000 \times g$ for $10 \mathrm{~min}$, the supernatant was centrifuged at $40,000 \times g$ for $1 \mathrm{hr}$. The resulting precipitated fractions were washed two times by homogenizing the pellet in $0.1 \mathrm{M}$ Tris- $\mathrm{HCl}, \mathrm{pH}$ 8.8 , containing $10 \%(\mathrm{w} / \mathrm{v})$ sucrose and centrifuging at $40,000 \times g$ for $1 \mathrm{hr}$. The final pellet was suspended in the same buffer containing $10 \%$ sucrose at a protein concentration of $3.5 \mathrm{mg} / \mathrm{ml}$ and heated at $60^{\circ} \mathrm{C}$ for $20 \mathrm{~min}$. The heated suspension was cooled and centrifuged at $40,000 \times g$ for $2 \mathrm{hr}$. From the final pellet, $43 \%$ of its enzyme activity was recovered in the supernatant. The solubilized enzyme was used for experiments on catalytic properties of the enzyme.

\section{RESULTS AND DISCUSSION}

\section{Isolation of bacteria}

From 120 soil samples, 90 strains appeared on agar plates, which could assimilate nitrate as a nitrogen source. Thirteen strains grew in static culture in test tubes, and all strains accumulated nitrite in the medium. The observations suggest that these strains produced nitrate reductase in static culture. The organisms were anaerobically cultured in the shaking flask completely filled with medium, and the nitrate reductase activity of cells was assayed. Strains MY-12, MY-30 and MY-62, all isolated from soils of rice field, grew well (over $1.5 \mathrm{~g} \cdot$ wet cell/liter) and produced the enzyme in high quantity (over 3000 units/liter). Strain MY-12 produced the most enzyme of three strains and was used for the following 
experiments.

\section{Identification of strain $M Y-12$}

Strain MY-12 was subjected to identification to determine the taxonomical positon of nitrate reductase-producing microorganism. The morphological and physiological properties of the strain are listed in Table I. The strain was a Gram-negative rod and fermentative in $\mathrm{O}-\mathrm{F}$ test, and made TSI agar yellow. The results show that the strain belongs to Enterobacteriaceae. The physiological tests of the strain was further examined, as contrasted with cultures belonging to the family. Strain MY-12 closely resembled $E$. cloacae IFO 12935 in gas production from various sugars except lactose, decarboxylase activities for lysine, arginine and ornithine, and other physiological properties. Strain MY-12 produced gas rapidly from lactose, whereas gas production from the sugar in $E$. cloacae IFO 12935 was very slow. The isolated strain MY-12 was thus identified

Table I. Morphological and Physiological Properties of Strain MY-12

Rods, 0.5 to 1.0 by 1.5 to 2.5 microns. Motile with peritrichous flagella. Gram-negative.

Nutrient agar colonies: Circular, smooth, entire, flat to convex, yellowish white, glistening, butyrous, transparent, growth abundant.

Nutrient agar slant: Spreading, yellowish white, glistening, butyrous, medium unchanged, transparent, growth abundant.

Nutrient broth: Turbid with sediment.

Gelatin stab: Liquefaction, growth abundant

Litmus milk: Acid, not decolorized, coagulated

B.C.P. milk: Acid, coagulated.

TSI agar: Yellow, gas production, hydrogen sulfide not formed.

O-F test: Fermentative. Methyl red test: Negative. V.P. test: Positive. I.P.A. test: Negative.

Cytochrome oxidase: Negative. Catalase: Positive. Ureas: Positive. Citrate and acetate utilized.

Gas from glucose, sorbitol, rhamnose, cellobiose, arabinose, raffinose and lactose

No gas from starch, glycerol and inositol.

Arginine and ornithine decarboxylases: Positive. Lysine decarboxylase: Negative.

Good growth at $20^{\circ} \mathrm{C}$ to $45^{\circ} \mathrm{C}$. Good growth at $\mathrm{pH}$ 4.5 to $\mathrm{pH} 9.5$.

Facultatively anaerobic. as E. cloacae (Jordan) Hormaeche and Edwards.

\section{Growth conditions for enzyme production}

Effects of metals. Table II shows that the addition of $\mathrm{Fe}^{2+}$ to the medium promoted cell growth and enzyme production. The total enzyme activity in cells cultured in basal medium containing $5 \mathrm{mg} /$ liter of $\mathrm{FeSO}_{4} \cdot 7 \mathrm{H}_{2} \mathrm{O}$ without molybdate was about 8 times that in cells cultured without these metals. The supply of molybdate to the medium, in addition of $\mathrm{Fe}^{2+}$ further promoted enzyme production. In the following tests for growth conditions, $5 \mathrm{mg} /$ liter of $\mathrm{FeSO}_{4} \cdot 7 \mathrm{H}_{2} \mathrm{O}$ was supplied to the basal medium. Iron and molybdenum were reported to exist in respiratory nitrate reductase of $E$. coli $i^{7)}$ and $B$. licheniformis. ${ }^{6)}$ The enzyme of $E$. cloacae MY-12 also seems to have these metals.

Effects of $\mathrm{C}$ - and $\mathrm{N}$-sources. The amounts of $\mathrm{NH}_{4} \mathrm{Cl}$ and glucose in medium did not influence enzyme production per cell much, but influenced cell growth. As a result, the proper supply of these compounds increased total enzyme activity.

Effects of natural media. The addition of

Table II. Effects of Metals on Growth ANd ENZyMe Production of E. cloacae $\mathrm{MY}-12$

$\mathrm{FeSO}_{4} \cdot 7 \mathrm{H}_{2} \mathrm{O}$ or $\mathrm{Na}_{2} \mathrm{MoO}_{4} \cdot 2 \mathrm{H}_{2} \mathrm{O}$ or both were added to basal medium.

\begin{tabular}{|c|c|c|c|c|}
\hline \multirow{2}{*}{$\begin{array}{c}\mathrm{FeSO}_{4} \cdot 7 \mathrm{H}_{2} \mathrm{O} \\
(\mathrm{mg} / \text { liter })\end{array}$} & \multicolumn{4}{|c|}{$\mathrm{Na}_{2} \mathrm{MoO}_{4} \cdot 2 \mathrm{H}_{2} \mathrm{O}(\mathrm{mg} /$ liter $)$} \\
\hline & 0 & 2 & 5 & 10 \\
\hline \multirow[b]{2}{*}{0} & $0.80^{a}$ & 0.89 & 0.86 & 0.71 \\
\hline & $0.45 \times 10^{4}$ units $/$ liter $^{b}$ & 0.71 & 0.70 & 0.53 \\
\hline \multirow{2}{*}{2} & 0.93 & $1: 07$ & 1.09 & \\
\hline & 2.51 & 2.85 & 3.03 & \\
\hline \multirow{2}{*}{5} & 1.10 & $1.10^{\circ}$ & 0.98 & 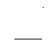 \\
\hline & 3.43 & 4.16 & 3.57 & \\
\hline \multirow{2}{*}{10} & 1.07 & & & \\
\hline & 2.21 & 一 & - & - \\
\hline
\end{tabular}

a Upper row, growth (O.D. at $660 \mathrm{~nm}$ )

$b$ Lower row, total activity. 
Table III. Effects of Natural Media on Growth and Enzyme Production

Polypepton, and meat extract and/or yeast extract were added to basal medium containing $5 \mathrm{mg} / \mathrm{liter}$ of $\mathrm{FeSO}_{4} \cdot 7 \mathrm{H}_{2} \mathrm{O}$ and $10 \mathrm{~g}$ /liter of glucose.

\begin{tabular}{|c|c|c|c|}
\hline Natural media & (g/liter) & $\begin{array}{l}\text { Growth } \\
\text { (O.D. at }\end{array}$ & $\begin{array}{c}\text { Total activity } \\
\text { (units/liter) }\end{array}$ \\
\hline Polypepton & 0.5 & 1.26 & 3.81 \\
\hline & 1 & 1.39 & 5.10 \\
\hline & 2 & 1.86 & 9.03 \\
\hline & 5 & 2.24 & 7.60 \\
\hline & 10 & 2.60 & 5.77 \\
\hline & 20 & 2.71 & 4.79 \\
\hline Meat extract & 2 & 1.43 & 4.39 \\
\hline & 5 & 1.57 & 5.01 \\
\hline & 10 & 1.77 & 7.14 \\
\hline & 20 & 2.24 & 6.43 \\
\hline Yeast extract & 0.5 & 1.45 & 5.91 \\
\hline & 1 & 1.63 & 4.94 \\
\hline & 2 & 1.86 & 5.47 \\
\hline Yeast extract & Polypepton & & \\
\hline 0.5 & 2 & 2.04 & 4.87 \\
\hline 0.5 & 10 & 2.56 & 6.53 \\
\hline Meat extract & Polypepton & & \\
\hline 10 & 2 & 2.32 & 6.16 \\
\hline 10 & 10 & 2.63 & 5.40 \\
\hline Yeast extract & Meat extract & & \\
\hline 0.5 & 10 & 2.74 & 4.10 \\
\hline $\begin{array}{c}\text { Polypepton } \\
2\end{array}$ & & & \\
\hline
\end{tabular}

Polypepton (Daigoeiyo), and meat extract (Riken Vitamin) and/or yeast extract (Daigoeiyo) increased cell growth, but enzyme production varied. The strain produced the most enzyme in medium containing $2 \mathrm{~g} /$ liter of Polypepton, as shown in Table III.

Effect of nitrate. Table IV shows the effect of nitrate on cell growth and enzyme production. E. cloacae MY-12 grew anaerobically without nitrate in the presence of $\mathrm{NH}_{4} \mathrm{Cl}$ or polypeptone as a $N$-source, but nitrate reductase activity in the strain was very low. The addition of 0.5 to $1 \mathrm{~g} /$ liter of $\mathrm{NaNO}_{3}$ increased enzyme production. But growth of the strain was inhibited in medium containing over
TABLE IV. EFFECT OF $\mathrm{NaNO}_{3}$ ON Growth and Enzyme Production

$\mathrm{NaNO}_{3}$ was added to optimal medium.

\begin{tabular}{ccc}
\hline $\mathrm{NaNO}_{3}$ (g/liter) & $\begin{array}{c}\text { Growth } \\
\text { (O.D. at 660 nm) }\end{array}$ & $\begin{array}{c}\text { Total activity } \\
\text { (units/liter) }\end{array}$ \\
\hline $0^{a}$ & 0.98 & $0.44 \times 10^{4}$ \\
0 & 1.49 & 0.85 \\
0.5 & 2.09 & 6.43 \\
1 & 1.86 & 9.03 \\
2 & 1.26 & 5.98 \\
3 & 1.01 & 4.04
\end{tabular}

a The sole nitrogen source was $1 \mathrm{~g} /$ liter of $\mathrm{NH}_{4} \mathrm{Cl}$ without Polypepton.

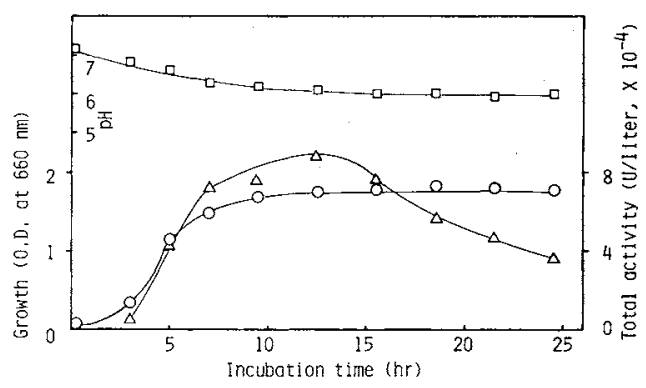

FIG. 1. Time Course of Growth and Enzyme Production of E. cloacae MY-12.

The strain was anaerobically cultured in optimal medium at $30^{\circ} \mathrm{C}$.

$\bigcirc-\bigcirc$, growth; $\triangle-\triangle$, total activity; $\square-\square, \mathrm{pH}$.

$2 \mathrm{~g} /$ liter of $\mathrm{NaNO}_{3}$, although enzyme activity per cell did not decrease so much. In these media, a high concentration of nitrite was detected after incubation for $13 \mathrm{hr}$, which seemed to inhibit growth of the strain in high concentration of nitrate.

From these growth condition tests, the optimal medium for enzyme production consisted of the following per liter: $\mathrm{Na}_{2} \mathrm{HPO}_{4}$. $12 \mathrm{H}_{2} \mathrm{O}, 15 \mathrm{~g} ; \mathrm{KH}_{2} \mathrm{PO}_{4}, 3 \mathrm{~g}$; glucose, $10 \mathrm{~g}$; $\mathrm{NaNO}_{3}, 1 \mathrm{~g} ; \quad \mathrm{NH}_{4} \mathrm{Cl}, \quad 0.1 \mathrm{~g} ; \mathrm{NaCl}, 0.5 \mathrm{~g}$; $\mathrm{MgSO}_{4} \cdot 7 \mathrm{H}_{2} \mathrm{O}, 0.2 \mathrm{~g} ; \mathrm{Na}_{2} \mathrm{MoO}_{4} \cdot 2 \mathrm{H}_{2} \mathrm{O}, 2 \mathrm{mg}$; $\mathrm{FeSO}_{4} \cdot 7 \mathrm{H}_{2} \mathrm{O}, 5 \mathrm{mg}$; and Polypepton, $2 \mathrm{~g}$; $\mathrm{pH} 7.1$.

Time course of growth and enzyme production

Figure 1 shows that $E$. cloacae MY-12 
produced the maximal quantity of enzyme in optimal medium from the end of exponential phase to the origin of stationary phase, that is, after incubation for 12 to $13 \mathrm{hr}$. The total enzyme activity gradually decreased in the stationary phase, but maintained half the maximal level even after incubation for $24 \mathrm{hr}$. The $\mathrm{pH}$ value of medium was varied from the original $\mathrm{pH} 7.1$ to 6.0 .

\section{Comparison of specific activity with other strains}

The specific activity of nitrate reductase of E. cloacae MY-12 was compared with that of enzymes (respiratory type) reported in other strains. When $E$. cloacae MY-12 accumulated the most enzyme under optimal growth conditions $\left(9.03 \times 10^{4}\right.$ units/ liter, see Table III), the specific activity of enzyme in the cell-free extract prepared by disruption with the ultrasonic oscillator was 158 units/mg. The enzyme value was the second highest of six strains listed in Table V, although the enzyme activities of $M$. denitrificans and Micrococcus halodenitrificans were assayed at $37^{\circ} \mathrm{C}$.

\section{Localization of enzyme in cells}

Cell-free extract of $E$. cloacae MY-12 obtained by lysozyme digestion and sonic disruption was fractionated by centrifugation at $40,000 \times g$ for $2 \mathrm{hr}$, after the whole cells were removed. Eightly-one percent of nitrate reductase was detected in the precipitated fraction. The observation showed that the enzyme formed in anaerobic culture of the strain is principally membrane-bound and seems to belong to the respiratory type. ${ }^{9}$

\section{Optimal $\mathrm{pH}$}

Nitrate reductase solubilized from membrane of E. cloacae MY-12 had the optimal $\mathrm{pH}$ at 7.1 for $\mathrm{NO}_{3}{ }^{-}$as an electron acceptor (Fig. 2(a)). The optimal pH of enzymes of $E$. coli $^{2)}$ and $K$. aerogenes ${ }^{5)}$ was 7.1 and 6.9 , respectively, whereas that of $M$. denitrificans $^{3)}$ and $M$. halodenitrificans ${ }^{17)}$ was $5.6 \sim$
Table V. Specific Activity of Respiratory Nitrate Reductase Produced By Various STRaINS

\begin{tabular}{lcc}
\hline \multicolumn{1}{c}{ Strains } & $\begin{array}{c}\text { Specific activity } \\
\text { (units/mg) }\end{array}$ & References \\
\hline E. cloacae MY-12 & 158 & This study \\
K. aerogenes & 40 & 5 \\
E. coli $\mathrm{K}-12$ & 100 & 16 \\
B. licheniformis & 14 & 6 \\
M. denitrificans & $75^{a}$ & 3 \\
M. halodenitrificans & $250^{\circ}$ & 17 \\
\hline
\end{tabular}

a Enzyme activity was assayed at $37^{\circ} \mathrm{C}$.

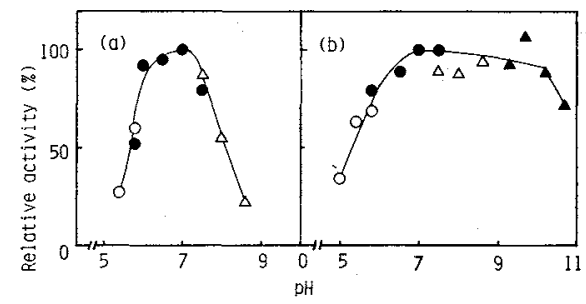

FIG. 2. Optimal pH (a) and pH-Stability (b) of Solubilized Nitrate Reductase.

(a) Optimal pH: The enzyme activity $(0.5$ units of enzyme) was assayed in buffers of various $\mathrm{pH}$ values with ionic strength 0.13 at $30^{\circ} \mathrm{C}$. (b) pH-Stability: The enzyme (1.5 units) was incubated in buffers of various $\mathrm{pH}$ values with ionic strength 0.2 , containing $10 \%$ sucrose at $5^{\circ} \mathrm{C}$; After $20 \mathrm{hr}$, the remaining activity was assayed at $\mathrm{pH} 7.1$. The buffers used were: $\mathrm{O}-\mathrm{O}, \mathrm{CH}_{3} \mathrm{COOH}-$ $\mathrm{CH}_{3} \mathrm{COONa} ;-\mathrm{KH}_{2} \mathrm{PO}_{4}-\mathrm{Na}_{2} \mathrm{HPO}_{4} ; \triangle-\triangle$, Tris$\mathrm{HCl} ; \boldsymbol{\Delta}-\boldsymbol{\Delta}, \mathrm{NaHCO}_{3}-\mathrm{Na}_{2} \mathrm{CO}_{3}$.

5.8 and 6.3 , respectively. From these data, the nitrate reductase of $E$. cloacae MY-12 seems to have a similar optimal $\mathrm{pH}$ to $E$. coli and $K$. aerogenes rather than to the two strains belonging to the genus Micrococcus.

\section{pH-Stability and thermostability}

The solubilized nitrate reductase of $E$. cloacae MY-12 lost about three-fourth of its activity after storage for $24 \mathrm{hr}$ at $5^{\circ} \mathrm{C}$ in $0.1 \mathrm{M}$ Tris- $\mathrm{HCl}, \mathrm{pH} 8.8$, without sucrose. However, the enzyme maintained over $90 \%$ of activity after 24 -hr storage at $5^{\circ} \mathrm{C}$ in buffer containing $10 \%$ sucrose, so that the $\mathrm{pH}$ stability and thermostability of the enzyme were tested in buffers containing $10 \%$ 


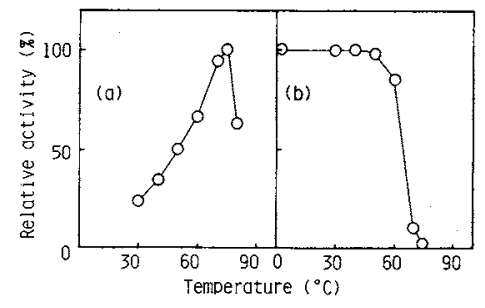

FIG. 3. Effect of Temperature on Enzyme Activity (a) and Its Thermostability (b).

(a) Effect of temperature: The enzyme activity $(0.05$ units of enzyme) was assayed at various temperatures and at $\mathrm{pH} 7.1$ in 5-min reaction. (b) Thermostability: The enzyme ( 2.5 units) was incubated in $0.1 \mathrm{M}$ Tris- $\mathrm{HCl}$ buffer, $\mathrm{pH} 8.8$, containing $10 \%$ sucrose at various temperatures. After $10 \mathrm{~min}$, the remaining activity was assayed at $30^{\circ} \mathrm{C}$ and $\mathrm{pH} 7.1$.

sucrose. Figure 2(b) shows that the enzyme was stable in a $\mathrm{pH}$ range from 6.5 to 10 . The enzyme was stable up to $50^{\circ} \mathrm{C}$, and at $60^{\circ} \mathrm{C}$ about $85 \%$ of activity was maintained (Fig. 3(b)). Heat treatment of the enzyme of $E$. coli ${ }^{2}$ at $60^{\circ} \mathrm{C}$ in buffer without sucrose was reported to cause no inactivation. These data show that the enzyme of $E$. cloacae MY-12 was somewhat unstable to heat treatment at $60^{\circ} \mathrm{C}$ compared with $E$. coli, although the enzyme of E. cloacae MY-12 was incubated in buffer containing $10 \%$ sucrose.

\section{Effect of temperature on enzyme activity}

The enzyme of $E$. cloacae MY-12 had maximal activity at $75^{\circ} \mathrm{C}$ in 5 -min reaction, as shown in Fig. 3(a).

\section{REFERENCES}

1) C. M. Brown, D. S. Macdonald-Brown and J. L. Meers, "Advances in Microbial Physiology," Vol. XI, ed. by A. H. Rose and D. W. Tempest, Academic Press Inc., New York, N.Y., 1974, p. 1.

2) S. Taniguchi and E. Itagaki, Biochim. Biophys. Acta, 44, 263 (1960).

3) P. Forget, Eur. J. Biochem., 18, 442 (1971).

4) C. H. MacCregor, C. A. Schmaitman, D. E. Normansell and M. G. Hodgins, J. Biol. Chem., 249, 5321 (1974).

5) J. Van't Riet and R. J. Planta, Biochim. Biophys. Acta, 379, 81 (1975).

6) J. Van't Riet, F. B. Wientjes, J. Van Doorn and R. J. Planta, Biochim. Biophys. Acta, 576, 347 (1979).

7) K. Lund and J. A. DeMoss, J. Biol. Chem., 251, 2207 (1976).

8) J. Van't Riet, J. H. Van Ee, R. Wever, B. F. Van Gelder and R. J. Planta, Biochim. biophys. Acta, 405, 306 (1975).

9) M. K. Showe and J. A. DeMoss, J. Bacteriol., 95, 1305 (1968).

10) D. J. D. Nicholas and A. Nason, "Methods in Enzymology," Vol. III, ed. by S. P. Colowick and N. O. Kaplan, Academic Press Inc., New York, N.Y., 1957, p. 981.

11) J. L. Wray and P. Filner, Biochem. J., 119, 715 (1970).

12) O. H. Lowry, N. J. Rosebrough, A. L. Farr and R. J. Randall, J. Biol. Chem., 193, 265 (1951).

13) R. Sakazaki, "Bergey's Manual of Determinative Bacteriology," 8th ed., ed. by R. E. Buchanan and N. E. Gibbons, The Williams and Williams Co., Baltimore, Md., 1974, p. 324.

14) R. Sakazaki, "Chonai Saikin To Sono Ruijikin No Kan-ina Shirabekata," Eiken Kagaku, Tokyo, 1964, p. 9.

15) T. C. Stadtman, "Methods in Enzymology," Vol. XXII, ed. by W. B. Jakoby, Academic Press Inc., New York, N.Y., 1971, p. 64.

16) R. A. Clegg, Biochem. J., 153, 533 (1976).

17) J. P. Rosso, P. Forget and F. Pichinoty, Biochim. Biophys. Acta, 321, 443 (1973). 